\title{
Ikan Sati: Komposisi Musik Programa
}

\author{
Abdul Rozak ${ }^{1)}$, Martarosa ${ }^{2)}$, Asep Saepul Haris ${ }^{3)}$ \\ ${ }^{1223)}$ Program Pascasarjana, Institut Seni Indonesia (ISI) Padangpanjang \\ Jl. Bahder Johan Guguk Malintang, Padang Panjang-Kota Padang Panjang, Sumatera Barat 27118 \\ Email:.jacc.abdul@gmail.com ${ }^{1)}$, marta23365@gmail.com ${ }^{2)}$, asepsinaro@gmail.com ${ }^{3)}$
}

\begin{abstract}
Ikan Sati is a grouping of a prose of the people (legend) contained in the Sungai Janiah. The existence of the legend story Ikan Sati has an important role in society, formerly the story is considered as something unseen and sacred, but now the community and the government work together to utilize the story of legend Ikan Sati is to serve as a tourist destination. The community is consciously aware of the transformation of the legend story of the Ikan Sati, including changes in values, functions, and changes in the shape / structure of the existence of the legend. Background of the transformation of the legend of the Ikan Sati, inspired workers created a work of the composition of descriptive music by collaborating the instrument of convention (orchestra) with traditional instruments. In the use of motive processing techniques using conventional techniques (such as: repetition, sequence, imitation, augmentation, and diminuisi), and wearing a modern harmony. Creation methods undertaken in the realization of this work of art are carried out with several work groupings: Concept Development Method (Observation, Interview, Data Collection, and Concept Formulation); and Conceptualizing Methods (Exploration, Experimentation, and Applications). In the depiction of the transformation of the legend, the work of this musical composition is made in three parts, each titled: Ikek Janji, Salisiah (value transformation, and function), and Inok-an (transformation of form and structure). Furthermore, the work of this composition is presented in the hope of raising awareness of the existence of an oral culture contained in the community, in this case the story of the legend of Ikan Sati Sungai Janiah itself, and as a preservation (revitalization) of local artistic traditions.
\end{abstract}

Keywords : Ikan sati, Transformation, Legend, Programe Music Composition

\begin{abstract}
ABSTRAK
Ikan Sati merupakan sebuah pengelompokan sebuah prosa rakyat (legenda) yang terdapat di Sungai Janiah. Cerita legenda ini dianggap masyarakat benar-benar terjadi pada dahulunya dan diturunkan secara turun-temurun di dalam masyarakat Sungai Janiah. Masyarakat secara sadar menyadari perubahan (transformasi) terhadap cerita legenda Ikan Sati tersebut, perubahan tersebut meliputi perubahan nilai, fungsi, dan perubahan bentuk/struktur terhadap keberadaan cerita legenda. Berlatar belakang dari perubahan (transformasi) terhadap cerita legenda Ikan Sati, pengkarya terinspirasi menciptakan sebuah karya komposisi musik programa/suasana (descriptive) dengan mengkolaborasikan instrumen konvensi (orkestra) dengan instrumen tradisi. Dalam penggunaan teknik pengolahan motif memakai teknik konvensional (seperti: repetisi, sekuen, imitasi, augmentasi, dan diminuisi), serta memakai garapan harmoni modern. Metode penciptaan yang dilakukan dalam perwujudan karya seni ini dilakukan dengan beberapa pengelompokan kerja: Metode Pengembangan Konsep (Observasi, Wawancara, Pengumpulan Data, dan Perumusan Konsep); dan Metode Mewujudkan Konsep (Eksplorasi, Eksperimentasi, dan Aplikasi). Dalam penggambaran transformasi terhadap cerita legenda, karya komposisi musik ini dibuat dalam bentuk tiga bagian, yang masing-masing diberi judul: Ikek Janji, Salisiah (transformasi nilai, dan fungsi), dan Inok-an (transformasi bentuk, dan struktur). Selanjutnya karya komposisi ini disajikan dengan harapan menimbulkan kesadaran terhadap keberadaan sebuah kebudayaan lisan yang terdapat di masyarakat, dalam hal ini cerita legenda Ikan Sati di Sungai Janiah itu sendiri, dan sebagai pelestarian (revitalisasi) terhadap kesenian tradisi lokal.
\end{abstract}

Kata kunci : Ikan sati, Transformasi, Legenda, Komposisi Musik Programa 


\section{Pendahuluan}

Sungai Janiah merupakan sebuah nama Jorong yang terdapat di Nagari Tabek Panjang, Kecamatan Baso, Kabupaten Agam, Sumatera Barat. Daerah ini dikenal sebagai daerah yang memiliki Legenda Ikan Sati (Ikan Sakti). Lokasinya terletak sekitar $3.5 \mathrm{~km}$ dari Pasar Baso Kabupaten Agam, lokasi tersebut dijadikan objek wisata alam yang mengandung nilai cerita rakyat (Legenda) sejak tahun 1936 (Adila, 2004: 25).

Objek wisata Ikan Sati ini berada tepat di antara Mesjid Darul Amal dan kaki Bukit Batanjua yang berupa sebuah kolam. Mesjid Darul Amal merupakan salah satu mesjid yang terdapat di Jorong Sungai Janiah, objek wisata ini tepat berada di belakang mesjid tersebut. Selanjutnya terdapat sebuah bukit yang terletak di atas objek Ikan Sati Sungai Janiah, menurut Nurmalis di atas bukit tersebut terdapat sebuah mata air yang dianggap keramat oleh masyarakat setempat (Wawancara pada tanggal 23 Februari 2018, di Nagari Sungai Janiah).

Objek wisata ini berbentuk kolam, di dalam kolam tersebut hidup ratusan ikan, ada sebagian yang tidak dikenal jenisnya, ikan tersebut berwarna merah dan abuabu, masyarakat hanya menamainya sebagai Ikan Sati (Ikan Sakti). Kolam ikan dengan luas $60 \mathrm{~m}^{2}$ ini sarat dengan cerita yang menurut cerita dari pemuka dan tetua di masyarakat bahwa ikan tersebut merupakan wujud kutukan akibat perseteruan antara manusia dengan bangsa jin (Adila, 2004: 25). Menurut Abdul Azis, perseteruan tersebut diawali dengan sebuah perjanjian yang dilanggar dan menyebabkan salah satu keturunan dari kedua bangsa tersebut dikutuk menjadi ikan. Perjanjian tersebut dinamakan dengan Sumpah Sati, selanjutnya hal tersebut menjadi awal mulanya masyarakat menamakan ikan tersebut sebagai Ikan Sati (Wawancara tanggal 23 Februari 2018, di Nagari Sungai Janiah).

Namun sekarang, cerita legenda ini sudah berubah secara bentuk/struktur, fungsi, dan nilai. Secara bentuk/strukur yaitu terlihat pada perencanaan pemerintah pada pengembangan fasilitas ke arah wisata tanpa memperhatikan kelangsungan ekologi, sosial dan budaya. Ini terlihat jelas pada pembangunan sarana dan prasarana wisata, pemeliharaan kolam ikan, serta usaha pemerintah dalam hal penyebarluasan informasi tentang keberadaan objek wisata ini. Sedangkan perubahan fungsi dan nilai terlihat dari cerita legenda yang awalnya hanya sebuah cerita di masyarakat lalu berubah menjadi sebuah tujuan destinasi wisata saja, pemerintah dan masyarakat yang mengedepankan tujuan wisata demi kelangsungan ekonomi.

Objek wisata Ikan Sati dimanfaatkan oleh masyarakat dan pemerintah sebagai investasi dan mendatangkan banyak manfaat melalui Wisatawan yang berkunjung ke objek wisata alam ini. Cerita yang berkembang dalam masyarakat sekarang hanya tinggal cerita, dan bukan suatu kepercayaan.

Menurut Sutrisno (2005: 68-69), perubahan nilai, fungsi, dan bentuk/struktur terhadap legenda Ikan Sati ini erat kaitannya dengan pandangan kaum sosiolog dan strukturalis yang tidak percaya bahwa manusia dengan kebudayaannya itu menentukan sejarah. Perubahan masyarakat kolektif menjadi individualis bukan karena faktor budaya merosotnya (krisisnya) nilai kebersamaan menjadi egois individualis, tetapi disebabkan oleh faktor-faktor material seperti perubahan ekonomi. Struktur sosial di mana keharusan untuk kompetisi agar "survival" juga menjadi tuntuan cara hidup bersaing dengan "survival of the fittest" di saat kebersamaan pemilikan dan kebersamaan kerukunan tidak lagi laku untuk kelangsungan hidup.

Sementara itu menurut Nuryahman (2013: 8), apabila praktik sosial baru merupakan pengulangan dari yang sebelumnya, atau walaupun kemasannya berbeda akan tetapi substansinya masih sama, maka yang terjadi adalah penguatan struktur. Sebaliknya, apabila praktik sosial yang baru dan berbeda dengan sebelumnya dan kemudian menjadi rutunitas baru yang diakui dan dirasakan manfaatnya oleh masyarakat, maka yang terjadi adalah transformasi struktur. Selanjutnya diperjelas oleh Sutrisno (2005: 9), masyarakat sebagai pelaku budaya cerita legenda Ikan Sati di Sungai Janiah sadar terhadap bagaimana perkembangan itu terjadi. Perkembangan terjadi diakibatkan oleh perubahan (transformasi) fungsi, nilai, dan bentuk/struktur. Perubahan-perubahan tersebut bisa direfleksikan ke dalam arus penggunaan istilah budaya yaitu yang mengacu pada perkembangan intelektual, spiritual, dan estetis dari seorang individu, sebuah kelompok, atau masyarakat.

Kehadiran cerita Legenda Ikan Sati di Sungai Janiah tersebut menimbulkan inspirasi pengkarya untuk mengekspresikan transformasi cerita Legenda Ikan Sati ke bentuk karya musik. Keterkaitan aspek historis cerita legenda Ikan Sati yang menyiratkan sebuah transformasi nilai, fungsi, dan bentuk/struktur menjadi ide bagi pengkarya untuk menciptakan sebuah karya musik, ide tersebut adalah: (1) Pelahiran penggambaran cerita legenda yang lahir, berkembang dan dipercaya oleh masyarakat, (2) Penggambaran perubahan nilai dan fungsi terhadap cerita legenda, dan (3) Wujud perubahan bentuk/struktur terhadap cerita legenda. Ketiga hal ini akan dikonsep untuk menciptakan pesan dan makna dari cerita legenda Ikan Sati ke dalam komposisi musik.

Konsep musik yang bisa mewakili dari konsep karya komposisi musik ini akan diciptakan adalah bentuk Musik Programa. Konsep Musik Programa tersebut menggambarkan suatu peristiwa cerita Legenda Ikan Sati di Sungai Janiah dalam bentuk, ruang, dan waktu, serta penyampaian pesan dan makna ke dalam komposisi musik (Descriptive). Selanjutnya, ide komposisi musik ini berasal dari pola melodi dan scale pada kesenian tradisi Gandang Tigo, serta wujud perubahan bentuk/struktur terhadap cerita yang menyiratkan pesan, makna dan harapan. Karya komposisi musik ini diberi judul: Komposisi Musik Programa: "Ikan Sati”.

\section{A. Metode}

Metode penciptaan yang dilakukan dalam perwujudan karya seni ini dilakukan dengan beberapa 
pengelompokan kerja. Adapun tahapan langkah kerja dalam proses penciptaan komposisi musik Ikan Sati adalah sebagai berikut: (1) Metode Pengembangan Konsep (Observasi, Wawancara, Pengumpulan data, dan Perumusan Konsep); (2) Metode Mewujudkan Konsep (Eksplorasi, Eksperimentasi, dan Aplikasi).

\section{Pembahasan}

\section{A. Deskripsi Karya}

Adanya keinginan untuk mengangkat sebuah fenomena budaya dan menjadikannya ke dalam sebuah bentuk seni pertunjukan, maka pengkarya harus mengekspresikan pemahaman tentang bagaimana penggambaran sebuah cerita legenda berkaitan dengan objek fenomena budaya yang digagas, yaitu legenda Ikan Sati di Nagari Sungai Janiah. Selanjutnya pengkarya mempresentasikan pemahaman tersebut ke dalam sebuah gagasan. Lalu, gagasan tersebut akan diwujudkan ke dalam bentuk yang dikemas menjadi sebuah karya komposisi musik yang memiliki konsep. Karya ini mengekspresikan transformasi nilai, fungsi, dan bentuk/struktur dari cerita Legenda Ikan Sati di Nagari Sungai Janiah ke dalam jenis musik programa descriptive untuk menyampaikan fenomena, pesan dan makna yang mempunyai bentuk, ruang, dan waktu. Ide musikal berasal dari idiom tradisi yang berasal dari Nagari Sungai Janiah sendiri yaitu kesenian tradisi "Gandang Tigo" berupa melodi dan scale.

Adapun penggambaran transformasi terhadap cerita legenda Ikan Sati yang diwujudkan ke dalam karya adalah sebagai berikut.

a. Masyarakat Sungai Janiah bersama cerita legenda Ikan Sati dalam kehidupan keseharian dahulunya, lalu cerita tersebut menyebar dan berkembang.

b. Kepercayaan masyarakat secara sadar terhadap cerita legenda, bahwa cerita tersebut benar-benar terjadi dahulunya, dan menganggapnya sebagai sesuatu yang gaib.

c. Perkembangan isu wisata oleh pemerintah terhadap cerita legenda di dalam masyarakat, masyarakat tidak sadar terhadap adanya perubahan (transformasi nilai).

d. Proses mufakat masyarakat dengan pemerintah.

e. Pemanfaatan cerita legenda Ikan Sati yang dijadikan sebagai sebuah tujuan wisata oleh masyarakat dan pemerintah (transformasi fungsi).

f. Penerimaan secara sadar masyarakat terhadap perubahan.

g. Wujud perubahan cerita legenda yang saat ini sudah dijadikan sebagai sebuah tujuan wisata (transformasi bentuk, dan struktur).

Penggambaran transformasi terhadap cerita legenda Ikan Sati di atas dalam komposisi musik digarap dengan memakai melodi dan scale yang terdapat pada kesenian tradisi "Gandang Tigo" sebagai sebuah kesenian tradisi Nagari Sungai Janiah. Karya komposisi musik ini dibuat dalam bentuk tiga bagian. Masing-masing diberi judul: Bagian pertama: "Ikek Janji", Bagian kedua: "Salisiah" (transformasi nilai, dan fungsi), Bagian ketiga: "Inokan" (transformasi bentuk, dan struktur). Melodi dan scale pada kesenian tradisi "Gandang Tigo" diwakili oleh alat-alat musik Orkestra, yang terdiri dari String Section, Woodwind Section, dan Percussion Section, serta memakai beberapa instrumen tradisi seperti Gandang Tigo, Talempong, dan Gandang Katindiak. Struktur yang dihadirkan dalam ide penggarapan komposisi Ikan Sati adalah sebagai berikut.

\begin{tabular}{|c|c|c|c|}
\hline $\begin{array}{c}\text { Judul } \\
\text { Komposisi }\end{array}$ & Bagian & $\begin{array}{c}\text { Sub. } \\
\text { Bagian }\end{array}$ & Keterangan \\
\hline \multirow{15}{*}{ Ikan Sati } & \multirow{5}{*}{$\begin{array}{l}\text { Ikek Janji } \\
\text { (Bagian I) }\end{array}$} & \multicolumn{2}{|c|}{ Introduction } \\
\hline & & Subjek a & Tema 1 \\
\hline & & \multicolumn{2}{|c|}{$\begin{array}{l}\text { Transisi } \\
\end{array}$} \\
\hline & & Subjek b & Tema 2 \\
\hline & & \multicolumn{2}{|c|}{ Codetta } \\
\hline & \multirow{5}{*}{$\begin{array}{c}\text { Salisiah } \\
\text { (Bagian II) }\end{array}$} & Subjek c & Tema 3 \\
\hline & & \multicolumn{2}{|c|}{ Transisi } \\
\hline & & Subjek d & Tema 4 \\
\hline & & Subjek e & Tema 5 \\
\hline & & \multicolumn{2}{|c|}{ Codetta } \\
\hline & \multirow{5}{*}{$\begin{array}{c}\text { Inok-an } \\
\text { (Bagian III) }\end{array}$} & \multicolumn{2}{|c|}{ Introduction } \\
\hline & & Subjek f & Tema 6 \\
\hline & & \multicolumn{2}{|c|}{ Transisi } \\
\hline & & Subjek g & Tema 7 \\
\hline & & \multicolumn{2}{|c|}{ Coda } \\
\hline
\end{tabular}

Pada masing-masing bagian dan sub bagian komposisi ini memiliki beberapa tema yang mewakili subjek penggambaran transformasi berdasarkan suasana yang diinginkan (subjek a-g). Adapun tema masingmasing bagian dan sub. bagian adalah sebagai berikut.

1. Bagian pertama; Ikek Janji.

Pada bagian ini adalah sebuah penggambaran cerita utuh yang berkembang di masyarakat, serta penggambaran bagaimana cerita legenda Ikan Sati lahir, berkembang dan dipercaya oleh masyarakat. Masyarakat bersama cerita legenda tersebut hidup dalam keseharian, dan masyarakat secara sadar menganggap cerita tersebut merupakan sebuah fenomena yang benar-benar terjadi dahulunya. Pada bagian ini menghadirkan suasana: religius, ketentraman kondusif, dan asli.

Bagian ini diawali dengan Introduction. Dihadirkan sebagai pembuka awal garapan komposisi musik, dengan tujuan untuk menggiring para pendengar pada sebuah suasana yang religius, dan ketentraman.

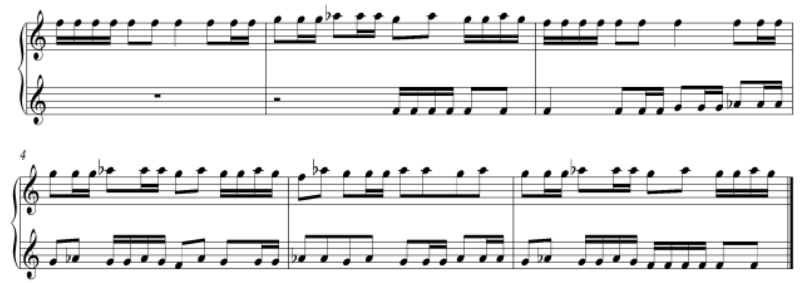

Notasi 1. Introduction Bagian I

Berikutnya dilanjutkan dengan Tema 1 yang merupakan Subjek a, dan diteruskan dengan permainan alat tradisi asli Gandang Tigo, sebagai interpretasi terhadap suasana kondusif dan asli. Selanjutnya Transisi sebagai pengantar sebelum masuk ke Tema 2 pada bagian I. Pada bagian ini merupakan 

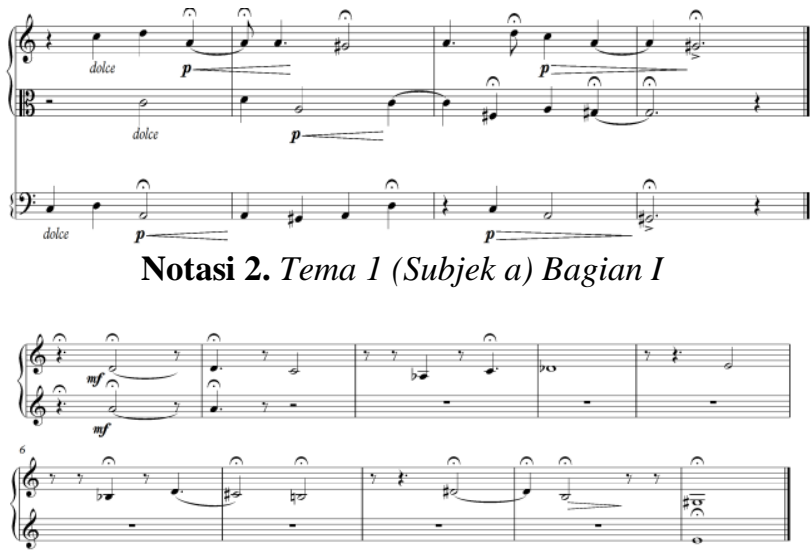

Notasi 3. Transisi Bagian I

Selanjutnya dilanjutkan dengan Tema 2 yang merupakan penggambaran pada Subjek b. Diteruskan dengan Codetta sebagai kalimat penutup pada bagian I, sekaligus sebagai pengantar sebelum masuk ke bagian II.

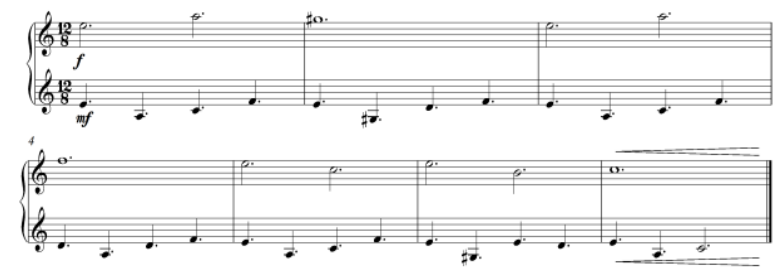

Notasi 4. Tema 2 (Subjek b) Bagian I

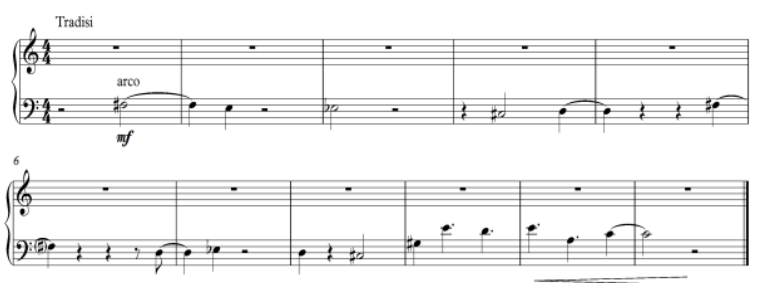

Notasi 5. Codetta Bagian I

\section{Bagian Kedua; Salisiah}

Pada bagian ini adalah ekspresi penggambaran usaha untuk melihat bagaimana nilai terhadap cerita legenda yang berkembang di masyarakat perlahan berubah. Penggambaran perubahan nilai dan fungsi yang secara tidak sadar terjadi pada cerita legenda ketika masyarakat dan pemerintah bekerjasama memanfaatkan serta menjadikan cerita legenda tersebut sebagai sebuah tujuan wisata. Pada bagian ini menghadirkan suasana: dilema, kegelisahan, kejanggalan, kerusakan, dan kegelisahan.

Pada bagian ini diawali dengan Tema 3 yang merupakan Subjek c. Diteruskan dengan Transisi sebagai pengantar sebelum masuk ke Tema 4, dan Tema 5 pada bagian II. Bagian ini merupakan interpretasi terhadap suasana dilema dan kegelisahan.

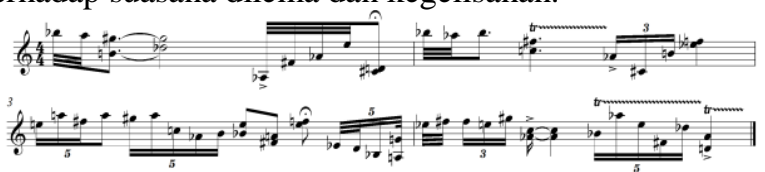

Notasi 6. Tema 3 (Subjek c) Bagian II

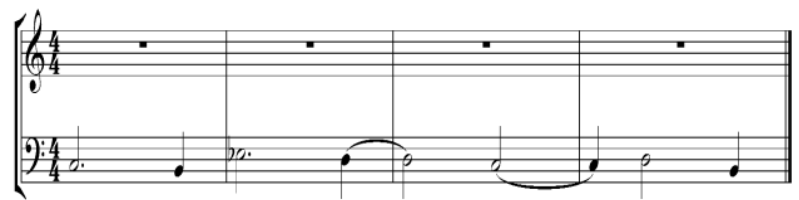

Notasi 7. Transisi Bagian II

Diteruskan dengan Tema 4 dan Tema 5 yang merupakan penggambaran masing-masing pada Subjek d dan Subjek e. Selanjutnya dilanjutkan dengan Codetta sebagai kalimat penutup pada bagian II, dan sebagai kalimat pengantar sebelum masuk ke bagian III. Bagian ini merupakan interpretasi terhadap suasana kejanggalan dan kerusakan.

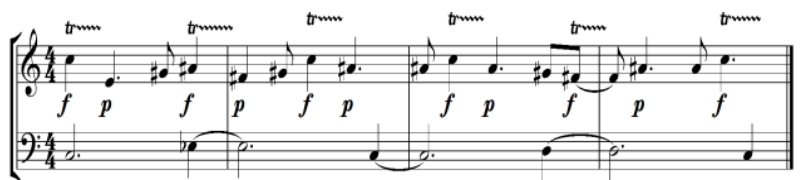

Notasi 8. Tema 4 (Subjek d) Bagian II

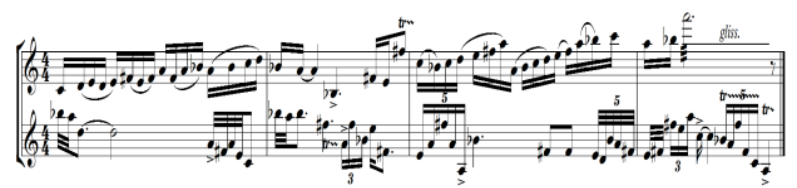

Notasi 9. Tema 5 (Subjek e) Bagian II

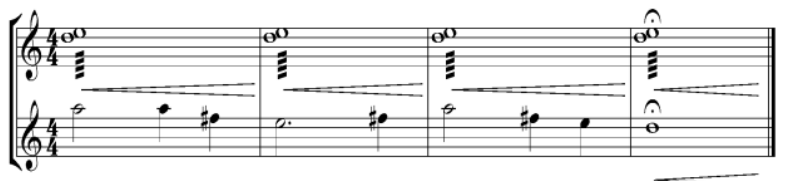

Notasi 10. Codetta Bagian II

\section{Bagian Ketiga; Inok-an}

Pada bagian ini adalah sebuah ekspresi penggambaran penerimaan di masyarakat tentang perubahan terhadap cerita legenda saat ini (Kekinian) di masyarakat, dilihat dari fungsi dan nilai yang sudah berubah mengikuti zaman, didesak oleh kebutuhan ekonomi. Wujudnya berupa perubahan bentuk/struktur terhadap cerita legenda yang sudah berubah menjadi sebuah tujuan wisata, wujud ini menyiratkan pesan, makna dan harapan. Pada bagian ini menghadirkan suasana: tenang, damai, kepasrahan, dan keharmonisan.

Pada bagian ketiga diawali dengan Introduction yang dihadirkan pada pembuka bagian III, dengan tujuan sebagai interpretasi terhadap perenungan secara sadar tehadap transformasi yang terjadi di masyarakat terhadap cerita legenda Ikan Sati, dan untuk menggiring pendengar pada suasana tenang dan damai.

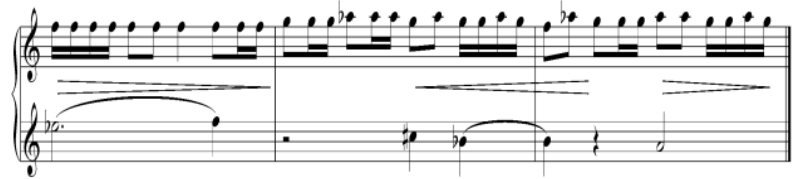

Notasi 11. Introduction Bagian III 
Selanjutnya diteruskan dengan Tema 6 dan Tema 7 yang pergantian ditandai dengan adanya transisi, dan merupakan penggambaran masing-masing pada Subjek $\mathrm{f}$ dan Subjek g. Pada kalimat terakhir ditutup dengan Coda (Permainan tradisi asli Gandang Tigo) sebagai kalimat penutup pada bagian III, sekaligus sebagai penutup semua bagian. Pada bagian ini merupakan interpretasi terhadap suasana kepasrahan dan keharmonisan.

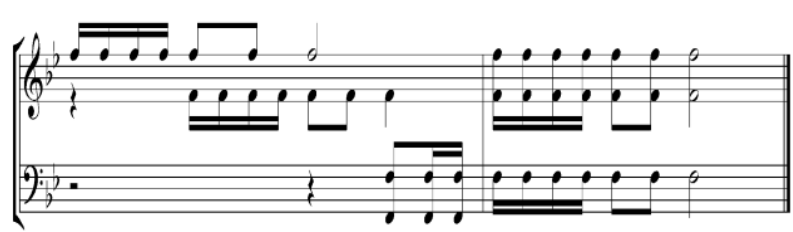

Notasi 12. Tema 6 (Subjekf) Bagian III

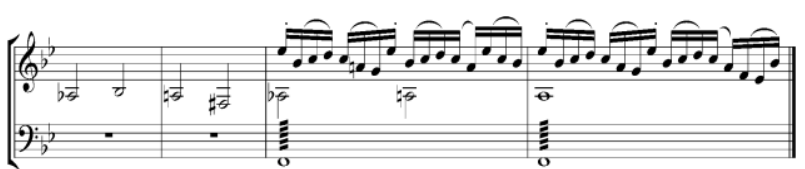

Notasi 13. Transisi Bagian I

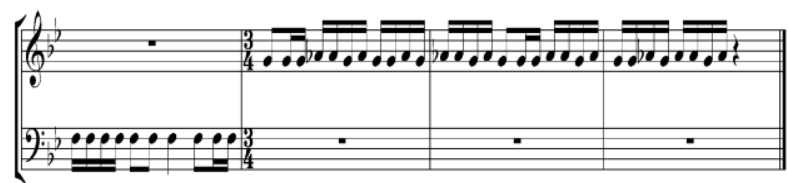

Notasi 14. Tema 7 (Subjek g) Bagian III

Pada penutup (Coda), dihadirkan permainan kesenian tradisi asli Gandang Tigo sebagai kalimat penutup pada bagian III. Coda juga digunakan sebagai penutup semua bagian.

\section{B. Analisis Karya}

1. Bagian Pertama; Ikek Janji

Bagian ini terdiri dari 87 birama, yang dibagi menjadi dua bagian yang diawali dengan Introduction, masing-masing bagian yaitu "Hiduik" (Tema 1), dan "Manusia" (Tema 2). Kedua bagian tersebut merupakan interpretasi penggambaran pada Subjek a dan Subjek b, selanjutnya kedua bagian itu ditandai dengan transisi pada bagian tengah dan codetta pada akhir bagian. Dapat dilihat dengan struktur sebagai berikut.

Bagian Introduction terdiri dari 17 birama dengan tempo ad-libitum, dan memakai sukat 4/4. Diawali dengan instrumen Timpani yang bermain rall pada nada B, D, dan F. Melodi pokok selanjutnya dimainkan oleh instrumen dengan memakai teknik Sekuen dan Canon. Lalu pada akhir frase ditandai dengan hentakan pada Timpani sebagai penanda akhir Introduction.

Bagian "Hiduik" terdiri dari 10 birama dimainkan dengan tempo ad-libitum memakai sukat 4/4. Diawali dengan memainkan melodi pokok secara repetisi dan sekuen pada String Section, melodi pokok juga memakai teknik pengolahan motif augmentasi dan diminuisi. Selanjutnya, frase transisi dimainkan pada instrumen Clarinet in Bes, dan Horn in F, dimainkan dengan tempo ad libitum dan sukat 12/8.
Bagian "Manusia" terdiri dari 32 birama dengan tempo Adagio dan memakai sukat 12/8. Diawali dengan Estabilishment of Accompaniment pada String Section dan Woodwind Section. Lalu, melodi pokok dimainkan setelah ditandai dengan adanya transisi, dengan memakai teknik pengembangan harmoni/orkestrasi pada seluruh. Diakhir dengan frase Codetta menghadirkan permainan tradisi Gandang Tigo, dengan Background Harmony pada String Section.

\section{Bagian Kedua; Salisiah}

Bagian ini terdiri dari 119 birama, dibagi dalam tiga bagian yang masing-masing terdiri dari "Dosa" (Tema 4), "Kana" (Tema 3), dan "Sasa" (Tema 4), ditandai dengan transisi pada bagian tengah dan codetta pada bagian akhir bagian. Pada ketiga bagian tersebut merupakan interpretasi penggambaran pada Subjek c, Subjek d, dan Subjek e. Dapat dilihat dengan struktur sebagai berikut.

Bagian "Dosa" terdiri dari 33 birama dengan sukat 4/4 yang dimainkan oleh instrumen Violin Solo. Melodi pokok dimainkan secara bebas (Ad-libitum) dalam interpretasi permainan. Melodi ini memakai tanggan nada Chromatic Scale dan Hexatonic (C Promotheus Scale, C Six-tone Symmetrical, C Whole Tone, dan C Promotheus Neopolitan). Selanjutnya bagian transisi dimainkan oleh instrumen Snare Drum, Floor, Timpani, Cymbals dan Chinese Gong.

Bagian "Kana" terdiri dari 23 birama dengan sukat 4/4 dn 5/4. Diawali dengan Estabilishment of Accompaniment yang dimainkan instrumen Trombone, dan selanjutnya melodi pokok dimainkan instrumen Clarinet in Bes dengan memakai Whole Tone, serta mencampurkan background harmony pada Brass Section dengan menggunakan minor scale.

Bagian "Sasa" terdiri dari 25 birama dengan memakai sukat 4/4. Melodi pokok dimainkan oleh instrumen Clarinet in Bes, Viola Solo dan Violin Solo secara bebas (Adlibitum) pada interpretasi permainan. Bagian ini merupakan rekapitulasi dari bagian Subjek c, dengan memakai teknik pengolahan motif sekuen, repetisi, augmentasi, dan diminuisi, serta memakai tangganada Hexatonic (C Promotheus Scale, C Six-tone Symmetrical, dan C Promotheus Neopolitan). Pada akhir frase (codetta) melodi pokok dimainkan pada instrumen Clarinet in Bes dan background harmony pada instrumen Violin Solo.

\section{Bagian Ketiga; Inok-an}

Bagian ini terdiri dari 122 birama dan dibagi menjadi dua bagian yang diawali dengan Introduction, masingmasing bagian terdiri dari "Surang" (Tema 6), dan "Basamo" (Tema 7), serta pada akhir frase diakhiri dengan coda. Kedua bagian mewakili penggambaran Subjek f dan Subjek g. Dapat dijabarkan dengan struktur berikut.

Bagian Introduction terdiri dari 10 birama dengan memakai sukat 4/4. Diawali dengan instrumen Violincello, Contrabass, Violin I, dan Violin II sebagai Background Harmony. Melodi pokok selanjutnya 
dimainkan oleh instrumen Vibraphone. Lalu pada akhir frase memainkan Full Orchestra sebagai penanda akhir Introduction.

Bagian "Surang" terdiri dari 22 birama dengan tempo Allegreto dan memakai sukat 3/4, 4/4, 5/4, dan 2/4. Diawali dengan memainkan melodi pokok secara repetisi dan sekuen pada String Section, melodi pokok juga memakai teknik pengolahan motif augmentasi dan diminuisi. Lalu, frase dilanjutkan dengan memainkan harmoni 2nd pada Woodwind Section. Pada akhir frase dilanjutkan dengan pengembangan tema sebelum transisi.

Bagian "Basamo" terdiri dari 63 birama dengan tempo Allegreto dan memakai sukat 5/4, 3/4, dan 2/4. Diawali dengan memainkan melodi secara sekuen pada String Section. Lalu, melodi pokok dimainkan dengan memakai teknik diminusi pada instrumen Clarinet in Bes dan Flute dengan background harmony pada String Section dan Brass Section. Diakhir dengan frase Codetta yang dimainkan instrumen Violin II, dan ditutup dengan permainan unisono pada instrumen Horn in $F$, Trombone, Violincello, dan Contrabass, serta intrumen Grandcassa dan Gong. Dan frase diakhiri (coda) pada permainan tradisi asli Gandang Tigo.

\section{Kesimpulan}

Cerita legenda Ikan Sati merupakan sebuah cerita yang diturunkan secara turun-temurun dalam masyarakat Sungai Janiah. Keberadaan cerita tersebut dahulunya merupakan sebuah cerita yang dianggap dan dipercayai benar-benar terjadi. Karena memiliki peranan penting dalam masyarakat, cerita tersebut kini berubah (bertransformasi) menjadi sebuah tujuan wisata saja, hal ini dimanfaatkan masyarakat dan pemerintah sebagai investasi dan mendatangkan banyak wisatawan. Perubahan (transformasi) itulah yang kemudian menginspirasi pengkarya untuk menciptakan sebuah karya komposisi musik instrumental, yang mengkolaborasikan penggunaan instrumen konvensi dengan tradisi. Karya komposisi ini disajikan dengan harapan menimbulkan kesadaran terhadap keberadaan sebuah kebudayaan lisan yang terdapat di masyarakat, dalam hal ini cerita legenda Ikan Sati itu sendiri, dan selanjutnya sebagai pelestarian terhadap kesenian tradisi lokal (revitalisasi). Adapun penyajian komposisi digambarkan ke dalam tiga bagian besar (Movement): Ikek Janji, Salisiah, dan Inok-an. Dalam penggunaan teknik pengolahan motif memakai teknik konvensional (repetisi, sekuen, imitasi, augmentasi, diminuisi, dan lain sebagainya), dan dengan memakai garapan harmoni modern.

\section{Daftar Pustaka}

Adilla, Ivan. 2004. Cerita Rakyat Dari Agam Sumatera Barat. Jakarta: Grasindo.

Amri, Iran. 2012. Dunia Kini, Laporan Karya Pascasarjana Institut Seni Indonesia
Padangpanjang. Padangpanjang: Institut Seni Indonesia Padangpanjang.

Alexander, Jannes. 2016. Filsafat Kebudayaan. Yogyakarta: Pustaka Pelajar.

Danandjaja, James. 2004. Buku Cerita Rakyat Sumatera. Grasindo: Jakarta.

2007. Folklor Indonesia Ilmu Gosip, Dongeng, dan lain-lain. Jakarta: PT. Pustaka Utama Grafiti.

Edmund, Karl Prier sj. 1993 Sejarah Musik Jilid 3. Yogyakarta: Pusat Musik Liturgi. 1993. Sejarah Musik Jilid 2. Yogyakarta: Pusat Musik Liturgi.

Nuryahman, dkk. 2013. Situs Makam Selaparang di Lombok Timur: Dalam Perspektif Pengajaran Sejarah dan Pengembangan Wisata Sejarah. Yogyakarta, Penerbit Ombak.

Persichetti, Vincent. 1978. Twentieth Century Harmony. London: Faber and Faber Limited.

Piston, Walter. 1959. Harmony. London: Victor Gollancz Limited.

1969. Orchestration. London: Victor Gollancz Limited.

Sadie, Stanley. 2002. The New Groove Dictionary of Music and Musician, Vol. 20. New York: Macmillan Publisher Limited.

Schoenberg, Arnold. 1969. Structural Functions of Harmony. London: Faber and Faber.

Stein, Leon. 1979. Structure and Style The Study and Analysis of Musical Form. New Jersey: SummyBichard Music Princeton.

Sunarto, Bambang. 2013. Epistemologi Penciptaan. Yogyakarta: IDEA Press.

Sutrisno, Mudji dan Hendar Putranto. 2005. Teori-Teori Kebudayaan. Yogyakarta: Kanisius.

Taruskin, Richard. 1996. Stravinsky and The Russian Traditions. Oxford: Oxford University Press.

\section{Video dan Audio}

Agam interview. 2018. "Interview of Ikan Sakti Sungai Janiah”. Agam.

Angku nan Basa interview. 2018. "Interview of Ikan Sakti Sungai Janiah”. Agam.

Ardinus interview. 2018. "Interview of Gandang Tigo". Agam.

Emrizal interview. 2018. "Interview of Gandang Tigo". Agam.

Irzal interview. 2018. "Interview of Gandang Tigo". Agam.

Mahzar interview. 2017. "Interview of Ikan Sakti Sungai Janiah”. Agam.

Nurmalis. 2018. "Interview of Ikan Sakti Sungai Janiah”. Agam. 